

\section{DAFTAR ISI}

Kata Pengantar .............................................................................................. ii

Daftar Isi ................................................................................................................. iv

Pendidikan Agama, Pancasila, dan Local Wisdom di Pendidikan Tinggi

(Analisis Penerapan Kurikulum Berbasis KKNI) ............................................. 1

\section{Fauzan}

Peningkatan Kompetensi Ekologis Mahasiwa PGMI Melalui Pengembangan

KKNI Berbasis Kearifan Lokal

Suriani Nur

Implementasi Kurikulum 2013 Tingkat Pendidikan Dasar Madrasah

Ibtidaiyah Negeri (MIN) di Kabupaten Aceh Selatan

Masni, Hanifuddin Jamin dan Maya Agustina

Perkembangan dan Perubahan Kurikulum Pendidikan Islam di Indonesia

(Tinjauan Historis, Sosiologis, Politis, Ekonomi dan Manajemen Negara) ..32

Husin

Pengembangan Perencanaan Pembelajaran Muatan Lokal pada Jenjang

Pendidikan Dasar

\section{Asep Ediana Latip}

Sinkronisasi KKNI dalam Bingkai Pendidikan Berbasis Syariat Islam 53

Muhaini, Mohd. Nasir

Analisis Pemerataan Pendidikan dan Implementasi Kurikulum

Multikultural pada Tingkat Pendidikan Dasar di Indonesia

Fidrayani, Qorihatul Fikriyah

Integrasi Nilai-Nilai Karakter dalam Tari Sigeh Pangunten dalam

Pendidikan

Nurul Afifah

Penanaman Nilai-Nilai Kearifan Lokal di MINU Purwosari Metro Utara ... 81

Binti Khoiriyah, Wahyu Kusumaningtyas, Nur Laili

The Revitalization of Local Wisdom of Mandailing Community As Learning

Source of Islamic Primary School

Maulana Arafat Lubis

Membangun Karakter Siswa Melalui Kearifan Lokal Kisah Pewayangan .101

Ali Ba'ul Chusna

Sekolah Inklusi: Pendidikan Karakter Berbasis Falsafah Adat

Minangkabau

Nina Suzanne

Tembang Dolanan Sebagai Suplemen Mata Pelajaran Akidah Akhlak MI 120 Saiful Islam

Peranan Budaya Sekolah Berbasis Islam dalam Membentuk Karakter Sosial

Siswa SD Islam Al Azhar 15 Pamulang 128

Khalimi, Annisa Qurota Ayun'i 


\title{
PENANAMAN NILAI-NILAI KEARIFAN LOKAL DI MINU PURWOSARI METRO UTARA
}

\author{
Binti Khoiriyah, Wahyu Kusumaningtyas, Nur Laili \\ Institut Agama Islam Ma'arif NU Metro Lampung \\ khoiriyahmaliki@gmail.com
}

\begin{abstract}
The purpose of this research is to find the local wisdom that is in values have developed here in minu and strategies that is in use in the planting of the local wisdom in minu values. Was used in the study design approach with a case study .Data collection in technique in full, observation, interviews and documentation. To obtain data is not tampered with used steps perseverance observation and triangulation .Data analyst technique be conducted by way of data collection, reduction, presentation of data and the withdrawal of conclusion. The results of the study showed that ( 1 ) be concluded there are values local keraifan induced in them in minu there are three i.e.: help one another, solidarity and gotongroyong. Those values are already covers all third middle is in piil pesenggiri which includes juluk-adek juluk-adek, nemui-nyimah, nengah-nyappur, sakai-sambaiyan, and titie gemattei (2) strategy in use in the planting of the local wisdom values in minu pengintegrasikan values through the local wisdom with a learning process, the local wisdom pengintegrasikan values with a culture of schools and the local wisdom with ekstrakulikuler
\end{abstract}

Keywords: Planting, the local wisdom values, $M I / S D$

\section{PENDAHULUAN}

Dunia pendidikan di Indonesia kebanyakan masih mengutamakan kecerdasan kongnitif saja, hal ini dilihat dari sekolah-sekolah yang mempunyai peserta didik dengan lulusan nilai tinggi, akan tetapi prilaku, sikap dan mental kepribadian yang masih kurang, sebagaimana nilai akademik yang mereka raih di bangku-bangku sekolah serta melihat dari kelulusan peserta didik yang ditentukan oleh hasil ujian akhir nasional sekolah saja. Hal tersebut diketahui dari banyaknya lembaga pendidikan yang berlomba meningkatkan kecerdasan otak, namun mengabaikan kecerdasan hati, jiwa dan prilaku, dari sinilah nampaknya pendidikan mengalami ketidak seimbangan dalam mencapai tujuan pendidikan yang hakiki (Aunillah \& Nurla Isna, 2011:13). Sehingga akibatnya sering dijumpai perilaku tidak terdidik yang dilakukan oleh kaum terdidik, seperti ditunjukkan kaum elit pemerintah yang banyak melakukan korupsi dan mempermainkan hukum, padahal mereka memiliki kecerdasan, ditambah lagi akhir-akhir ini sering terjadi kasus tawuran antar pelajar/mahasiswa, pembunuhan, pencurian, pemerkosaan, pencabulan yang di lakukan oleh anakanak di bawah umur dan lain sebagainya. Perilaku hidup yang demikian menjadi karakter masyarakat moderen yang sudah tidak memiliki rasa toleransi atau kepedulian terhadap sesama dan pada akhirnya melahirkan kesenjangan sosial yang berkepanjangan. Melihat kenyataan itulah, nilai-nilai kearifan lokal perlu diberlakukan untuk di negeri ini, salah satu caranya yaitu dengan mengoptimalkan peran sekolah dalam penanaman nilai-nilai kearifan lokal terhadap peserta didiknya. Selain itu juga pihak sekolah perlu bekerja sama 
dengan keluarga, masyarakat, dan elemen bangsa yang lain demi mensukseskan agenda besar untuk menanamkan nilai-nilai kearifan lokal kepada peserta didik sebagai calon penerus bangsa di masa yang akan datang, oleh karena itu tanggungjawab dalam penanaman nilai-nilai kearifan lokal bukan hanya kepada guru saja akan tetapi semua pihak juga harus terlibat seperti orang tua dan masyarakat.

Nilai-nilai kearifan lokal pada intinya bertujuan membentuk bangsa yang tangguh, kompetitif, berakhlak mulia, bermoral, bertoleransi, bergotong royong, berjiwa patriot, berkembang dinamis, berorientasi ilmu pengetahuan dan teknologi, yang semuanya dijiwai oleh iman dan takwa dan kepada Tuhan Yang Masa Esa berdasarkan Pancasila.

Penanaman nilai-nilai kearifan lokal kepada diri peserta didik menjadi sangat penting terlebih lagi untuk sekolah SD/MI karena yang akan menjadi pondasi, ibaratnya jika suatu bangunan di bangunkannya dengan pondasi yang kuat maka bagunan itu akan menjadi bangunan yang kuat pula dan begitu juga sebaliknya, oleh karena itu sangatlah penting untuk di tanamkan kepada anakanak sebagai pondasi untuk menjaga diri dari kebebasan dalam bergaul dan selain itu pentingnya penanaman nilai-nilai kearifan lokal kepada peserta didik agar peserta didik mampu bersaing, beretika, bermoral, sopan, santun dan berinteraksi dengan masyarakat. Pendidikan yang dibawah naungan kementrian agama lebih menekankan pada nilai-nilai keislamannya. Namun, jika pendidikan hanya menekankan pada nilai-nilai keislamannya saja tanpa melihat kearifan lokal inipun dianggap masih kurang. Peserta didik juga dituntut untuk dapat mengetahui pentingnya nilai-nilai kearifan lokal, agar peserta didik dapat lebih mencintai budayanya. Ketika budaya telah masuk kejati diri peserta didik, maka peserta didik tidak akan mudah terpengaruh oleh pengaruh budaya luar.

Kesuksesan seseorang tidak ditentukan semata-mata oleh pengetahuan dan kemampuan teknis (hard skill) saja, tetapi lebih oleh kemampuan mengelola diri dan orang lain (soft skill). Sehingga, penanaman nilai-nilai kearifan lokal pada pembelajaran sudah seharusnya diterapkan oleh guru kepada peserta didik, dan salah satu upaya penanaman niali-nilai kearifan lokal adalah dengan mengintegrasikan nilai-nilai kearifan lokal ke dalam kegiatan belajar mengajar, budaya sekolah seperti mengucapkan salam dan mencium tangan kepada guru atau orang yang ditemuinya yang lebih tua, membaca Al-qur'an sebelum memulai kegiatan belajar mengajar dan masih banyak lagi lainnya. Salah satu dari nilai-nilai kearifan budaya Lampung yang dapat di terapkan dalam pemealajaran adalah Nengab-Nyampur (aktif dalam pergaulan bermasyarakat dan tidak individualistis), dan Sakai-Sambaian (gotong royong saling membantu dengan anggota masyarakat lainnya). Kegiatan ekstrakulikuler, kegiatan di rumah yang sama dengan sekolah dengan ini diharapkan dapat menanamkan dan mengembangkan nilai-nilai kearifan lokal secara baik kepada peserta didik.

Usia sekolah dasar (sekitar 6-12 tahun) merupakan tahap penting bagi pembentukan nilai-nilai kearifan lokal. Kesadaran budaya tentunya harus sudah tertanam pada diri individu sejak dini, agar terhindar dari sikap fatalistic atau chaovenisme. Peran pendidikan dasar dalam hal ini menjadi sangat penting, 
sebagai upaya untuk mencegah munculnya sikap-sikap yang membedabedakakan suku dan budaya. Anak sekolah dasar mengalami perkembangan fisik dan motorik tak terkecuali perkembangan kepribadian, watak emosional, intelektual, bahasa, budi pekerti, dan moralnya yang bertumbuh pesat (Sigit Dwi Santana, 2007:121). Oleh karena itu, jika mengharapkan atau menghendaki nilainilai kearifan lokal dapat berhasil maka penanaman nilai-nilai kearifan lokal harus dimulai sejak masa kanak-kanak atau usia SD/MI.

Indonesia merupakan negara yang kaya akan suku dan budaya. Institusi pendidikan khusunya pendidikan dasar atau MI ini dapat dijadikan potensi keberagaman sebagai nilai lebih dalam pendidikan. Menurut Soetomo melalui proses belajar dan adaptasi pengetahuan dan kearifan lokal juga berfungsi untuk menyesuaikan dan menjaga harmoni dengan lingkungan fisik dan lingkungan alamnya, sedangkan menurut Tilaar kearifan lokal mempunyai nilai pedagogis karena bertujuan untuk mengatur tingkah laku yang bermanfaat bagi kepentingan masyarakat (Sularso, 2016:74). Dewasa ini banyak sekali peserta didik yang sudah mulai meninggalkan nilai-nilai kearifan lokal. Banyak peserta didik yang melakukan tindakan bulyying, tawuran, pergaulan bebas, dan banyak kita jumpai peserta didik yang masih SD pun sudah mulai merokok. Disinilah tugas dari institusi pendidikan untuk melakukan tindakan kuratif agar peristiwa atau perilaku peserta didik tersebut dapat dikurangi ataupun dihilangkan.

Kearifan lokal merupakan usaha untuk menemukan kebenaran yang didasarkan pada fakta-fakta atau gejala-gejala yang berlaku secara spesifik dalam sebuah budaya masyarakat tertentu. Proses ini akan menghasilkan pengetahuan yang menggambarkan tentang kearifan lokal itu sendiri, yaitu gambaran mengenai sikap atau tingkah-laku yang mencerminkan budaya asli suatu daerah tertentu. Hal ini dapat dijadikan sebagai sumber materi dan nilai-nilai yang harus ditanamkan dalam pembelajaran.

Penelitian yang telah dilakukan oleh Endah Marwanti (2016:62) menjelaskan bahwa revitalisasi budaya lokal (kearifan lokal) yang relevan untuk membangun pendidikan karakter. Hal ini dikarenakan kearifan lokal di daerah pada gilirannya akan mampu mengantarkan siswa untuk mencintai daerahnya. Kecintaan siswa pada daerahnya akan mewujudkan ketahanan daerah. Ketahanan daerah adalah kemampuan suatu daerah yang ditunjukkan oleh kemampuan warganya untuk menata diri sesuai dengan konsep yang diyakini kebenarannya dengan jiwa yang tangguh, semangat yang tinggi, serta dengan cara memanfaatkan alam secara bijaksana.

Penelitian terkait nilai-nilai kearifan lokal yang dilakukan oleh Dedi Rosala (2016) pembelajaran berbasis kearifan lokal merupakan pembelajaran yang menempatkan siswa sebagai pusat pembelajaran student centered daripada teacher centered. Kearifan yang tersimpan dalam seni tari pada masyarakat etnik merupakan sebuah kekayaan masalalu yang bersifat historikal, maka seni tari etnik yang dipelajari di berbagai sekolah memiliki potensi sebagai media memahami keberadaan masyarakat etnik tertentu. Oleh sebab itu pendidikan seni tari tidak hanya sebagai ketrampilan semata yang selesai pada waktu siswa dipresentasikan di depan puplik. Tetapi seni tari merupakan salah satu media 
untuk belajar mengolah rasa, nilai-nilai filosofis, religi,pandangan hidup, dan orentasi sosial.

Dalam dunia pendidikan sudah seharusnya sekolah-sekolah terutama sekolah dasar di lampung menanamkan nilai-nilai kearifan lokal lampung kepada peserta didiknya. Sehingga berdasarkan latar belakang yang sudah di paparkan diatas maka peneliti tertarik melakukan penelitian dengan judul "Penanaman Nilai-Nilai Kearifan Lokal di MINU".

\section{METODE PENELITIAN}

Berdasarkan permasalahan yang diteliti, jenis penelitian yang digunakan pada penelitian ini adalah pendekatan kualitatif, dengan jenis penelitian studi kasus. Dilihat dari sumber data, dalam pengumpulan data yang diperlukan dalam penelitian ini terdiri dari dua bagian, yaitu: a) Sumber Data Primer, sumber data primer adalah sumber-sumber yang memberikan data secara langsung dari tangan pertama atau merupakan sumber asli (Nasution, 2001:150) Sumber data primer merupakan data yang langsung dari narasumber yang dilakukan dengan jalan mengadakan wawancara. b) Sumber Data Sekunder, sumber data sekunder adalah sumber-sumber yang diambil dari sumber yang lain yang tidak diperoleh dari sumber primer (Anwar, 1998).

Untuk mengumpulkan data yang diinginkan dan diperlukan dalam penelitian ini, maka peneliti menggunakan teknik pengumpulan data sebagai berikut: (1) Observasi, (2) Wawancara (interview), (3) Dokumentasi. Teknik analisa data yang digunakan ialah analisa deskriptif kualitatif, karena datanya berupa kata-kata atau paragraf yang dinyatakan dalam bentuk narasi yang bersifat deskriptif mengenai peristiwa nyata yang terjadi di lapangan. Adapun langkah-langkah teknik analisa deskriptif kualitatif, penulis adopsi dari pandangan Miles, Hubermen, dan Yin yaitu:

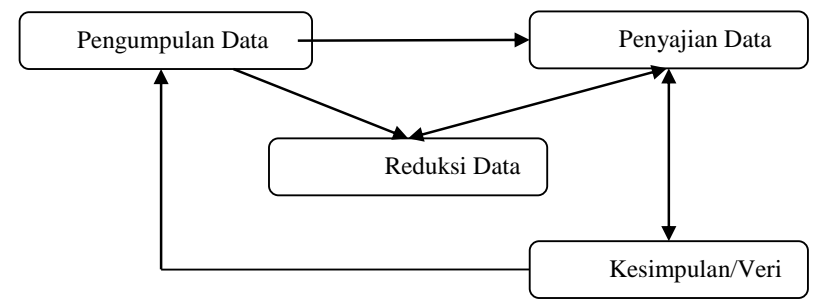

Gambar: 3.1. Teknis analisis data model interaktif (Sumber: B. Miles dan Huberman, 1992:299)

Secara singkat, komponen-komponen analisis data dikemukakan oleh Miles dan Huberman (1992:16) dapat dilihat penjelasan berikut ini: 1) Pengumpulan data, yaitu proses pengumpulan data mentah dimulai dengan memahami fenomena yang sedang diteliti, 2) Reduksi data, Yaitu proses pemilihan, pemusatan perhatian pada penyederhanaan, pengabstrakan, transformasi data kasar yang muncul dari catatan-catatan lapangan. Data yang diperoleh ditulis dalam bentuk uraian atau laporan terinci. Data laporan 
tersebut direduksi, dirangkum, dipilah, difokuskan pada subyek riset. Data yang direduksi memberikan gambaran yang lebih jelas tentang hasil pengamatan, juga mempermudah penulis mencari kembali data yang diperoleh, 3) Display data, ialah sajian kalimat yang disusun secara logis dan sistematis. Definisi lain ialah upaya menyajikan sekumpulan informasi sistematis yang memberikan kemudahan tentang berbagai hal yang terjadi, 4) Penarikan kesimpulan dan verifikasi, yaitu upaya mencari kesimpulan dari masalah yang diteliti. pada tahap ini kegiatan yang dilakukan adalah memberikan kesimpulan terhadap data-data hasil penafsiran. Verifikasi yaitu menguji kebenaran, kekokohan, dan mencocokkan makna-makna yang muncul dari data. Menarik kesimpulan (verifikasi data) yang diharapkan adalah data yang valid dan berkualitas, sehingga hasil penelitian yang dilakukan ini berkualitas tinggi dan baik.

\section{HASIL DAN PEMBAHASAN}

Hasil temuan peneliti diperoleh melalui observasi, wawancara dan dokumentasi bahwa di MINU telah menerapkan budaya yaitu: a) Tolong menolong. Tolong menolong adalah saling membantu sesama tanpa pamprih, hal ini terlihat ketika ada teman yang tidak membawa alat tulis seperti pena, penghapus, pensil, penggaris dll. Maka anak yang membawa alat tulis lebih meminjamkan kepada temannya yang membutuhkan atau meminjamkan dengan cara bergantian. b) Solidaritas, Solidaritas adalah perasaan setia kawan , hal ini terlihat ketika ada teman yang sedang sakit atau mendapatkan musibah mereka akan mengadakan penggalangan dana untuk membantu teman tersebut. c) Gotong royong. Gotong royong adalah kegiatan saling bantu membantu. Hal terlihat setiap anak di jadwalkan secara berkelompok untuk membersihkan kelas dan halam, selain itu setiap selai liburan guru, siswa dan seluruh masyarakat sekolah saling membantu membersihkan lingkungan sekolah.

Dari ketiga budaya tersebut sesuai dengan Piil Pesenggiri yang meliputi: a) Juluk-Adek Juluk-adek adalah identitas utama yang melekat pada orang Lampung. Juluk-adek diatur dalam tata cara adat. Karena juluk-adek berkaitan dengan masyarakat adat, setiap orang wajib menjaga juluk-adek yang sudah diberikan. Wajib menjaga sikap dan perilakunya di tengah masyarakat. b) Nemui-Nyimah Nemui-nyimah bermakna gemar bersilaturahmi atau berkunjung dan murah hati atau suka memberi. Nemui nyimah harus dilandasi dengan keikhlasan. Itu identitas orang Lampung yang harus dijaga. Dalam kondisi sekarang, nemui-nyimah harus benar-benar digalakkan demi terciptanya masyarakat yang aman, damai, saling bekerja sama, dan bergotong royong. c) Nengah-Nyappur Nengah-nyappur bermakna sikap toleran antarsesama, menjunjung tinggi rasa kekeluargaan. Dalam masyarakat Lampung yang plural, prinsip nengah-nyappur ini wajib dijunjung tinggi agar tercipta tatanan sosial yang harmonis. d) Sakai-Sambaiyan Sakai sambaiyan berarti tolong-menolong, solidaritas, dan gotong royong, setiap orang Lampung, semua yang ada di wilayah Lampung, wajib melakukan sakai-sambaiyan, saling tolong, membangun solidaritas, berpartisipasi pada semua program pembangunan yang sudah direncanakan oleh Pemerintah Indonesia maupun yang sudah dicanangkan oleh 
pemerintah daerah. e) Titie Gemattei Titie gemattei berarti mengikuti kebiasaan yang baik. Orang Lampung wajib mengikuti kebiasaan yang baik dari leluhur kita. Karena para leluhur sudah mewariskan budaya, adat, dan kearifannya, dan kita tinggal menjalankan. Tapi tidak berarti kita harus kaku dengan apa yang kita yakini, apa yang sudah lazim kita lakukan, karena titie gemattei juga mengajak kita untuk beradaptasi dengan perubahan, selama perubahan itu membawa ke arah yang lebih baik. Ambil hal-hal baru yang baik, dan pertahankan hal-hal lama yang baik.

Penanaman nilai-nilai keraifan lokal tidak hanya di kepada siswa saja tetapi seluruh masyarakat sekolah di MINUdi libatkan dalam penanaman nilainilai kearifan lokal. Adapun startegi yang digunakan dalam penanman nilai-nilai kearifan lokal di MINU yaitu: Penanaman nilai-nilai kearifan lokal melalui proses pembelajaran. Penanaman nilai-nilai kearifan lokal pada prinsipnya tidak bisa di lepaskan dari materi pelajaran, karena penanaman kearifan lokal harus di ajarkan kepada anak untuk dapat di terapkan dalam kehidupan sehari-hari sehinggap pembelajaran tiadak hanya menyentuh kepada ranah kognitif akan tetapi juga harus menyentuh ranah afektif, dan psikomotor. Begitu juga di MINU penanaman nilai-nilai kearifan lokal tidak berdiri sendiri akan tetapi menjadi satu kesatuan dengan setiap mata pelajaran di sekolah. Proses penanaman nilai-nilai kearifan lokal tidak dapat dilihat hasilnya dalam waktu yang singkat akan tetapi memerlukan waktu yang lama yang bersifat kontinu dan konsisten. Jadi tidak dapat di lakukan hanya dalam sekali waktu saja sehingga harus di integrasikan dalam kehidupan disekolah baik dalam proses pembelajaran di kelas maupun di luar kelas.

Strategi yang digunakan di MINU dalam penanaman nilai-nilai keraifan lokal kepada anak didiknya melaui cara-cara sebagi berikut: 1) Penanaman secara proporsional antara subtansi mata pelajaran dengan nilai-nilai kearifan lokal yang di tanamkan, 2) Mempertimbangkan tahap perkembangan siswa., 3) Mempertimbangkan baik dari bakat, minat dan kemampuan belajar, 4) Penanaman nilai-nilai kearifan lokal dilakukan melalui keteladanan dan pembiasaan sehari-hari, 5) Menciptakan suasana belajar dan lingkungann kelas yang mendukung pertumbuhnya nilai-nilai kearifan lokal yang positif bagi siswa.

Peran guru di MINU sebagai pendidik yang menanamkan nilai-nilai kearifan lokal anak juga sesuai dengan pendapat yang dikemukakan oleh Nurul Zuhriah (2007:105) yaitu: (1) guru harus menjadi model, (2) manjadikan sekolah menjadi masyarakat bermoral (3) mempratikkan moral disiplin, (4) menciptakan situasi demokratis di kelas (5) mewujudkan nilai-nilai melalui kurikulu, (6) membudayakan bekerja sama (7) menumbuhkan kesadaran berkarya (8) mengembangkan refleksi moral, dan (9) mengajarkan resolusi konflik.

a. Penanaman nilai-nilai kearifan lokal melalui budaya sekolah

Budaya sekolah merukan adat kebiasaan yang dilakukan di sekolah oleh semua masyarakat sekolah. Contoh budaya sekolah yang berkaitan dengan nilai-nilai kearifan lokal di MINU adalah sebagai berikut yaitu salam, senyum dan sapa ketika bertemu dengan orang, membesersihkan kelas bersamasama sebelum proses pembelajaran, membuang sampah pada tempatnya. 
Dengan diterapkan budaya sekolah melalui pembiasaan rutin sehari-hari diharapkan siswa dapat menanamkan nilai-nilai kearifan lokal dalam filosofi Sang Bumi Ruwa Jurai sebagai sistem nilai masyarakat Lampung, yang bersandarkan pada piil pesenggiri, Seperti yang telah dijelaskan di atas bahwa penanaman nilai-nilai kearifan lokal pada siswa tidak dapat dilihat hasilnya dalam waktu sebentar, penanaman nilai-nilai keraifan lokal membutuhkan waktu yang lama dan di lakukan secara terus menerus dan konsisten.

Prinsip penanaman nilai-nilai kearifan lokal di MINU adalah sebagai berikut:

1) Prinsip berkelanjutan

Proses berkelanjutan ini dimulai dari perencanaan, sosialisasi, pelaksanaan pengembangan dan evaluasi, langkah-langkah ini dilakukan secara terus menerus supaya budaya sekolah yang sudah terbentuk dapat di pertahankan dan di kembangkan lagi menjadi lebih baik.

2) Prinsip terpadu

Penanaman nilai nilai kearifan lokal secara terpadu yaitu dilakukan secara terintegrasi dengan seluruh aktivitas sekolah mulai dari proses pembelajaran, budaya sekolah, kegiatan ekstrakulikuler. Artiya seluruh aspek sekolah dirancang dan diarahkan agar dapat mendukung dalam penanman nilai-nilai kearifan lokal.

3) Prinsip konsistensi

Penanaman nilai-nilai kearifan lokal di MINU dilakukan secara konsisten. Dan di jalankan oleh seluruh masyarakat sekolah. Terutama kepala sekolah dan guru-guru karean mereka sebagia panutan untuk anak-anak didiknya.

4) Prinsip implementatif

Penanaman nilai-nilai kearifan lokal melalui budaya sekolah ini tidak akan berjalan dengan baik jika hanya melalui slogan, nasehat guru dikelas. Nilai-nilai kearifan lokal yang di tanamkan harus di wujudkan dalam bentuk ucapan, sikap dan prilaku. Oleh karean itu seluruh masyarakat sekolah dapat menerapakn dan mengangakat nilai-nilai kearaifan lokal dalam kehiduapn sehari-hari.

b. Penanaman nilai-nilai kearifan lokal melalui ekstrakulikuler

Kegiatan ekstrakulikuler ini adalah usaha sadar yang dilakukan pendidik dalam penanaman nilai-nilai kearifan lokal. Penanaman nilai-nilai kearifan lokal melalui kegiatan ekstrakulikuler ini sesuai dengan ungkapan Kemendiknas (Doni K, 2007:212) yang mengatakan bahwa "Aktivitas ekstrakulikuler yang selama ini diselenggarakan sekolah merupakan salah satu media strategis untuk pembinaan karakter dan peningkatan mutu akademik siswa". Strategi yang digunakan di MINU dalam penanaman nilai-nilai kearifan lokal melalui ektrakurikuler sanggar budaya, di sini siswa di perkenalkan dan di ajarkan tentang budaya lampung dari segi tari tradisional, musik tradisionl, lagu daerah, baju adat, rumah adat serta di ajarkan tentang filosofi Sang Bumi Ruwa Jurai sebagai sistem nilai masyarakat Lampung, yang bersandarkan pada piil pesenggiri, hal ini 
sebagi perlu di perkenalkan kepada anak didik seupaya generasi dapt melstarikan, menjaga dan mampu meberikan makna sesuai dengan perkembangan zaman.

\section{SIMPULAN}

Simpulan hasil penelitian yang ditemukan berdasarkan wawancara, observasi dan dokumentasi bahwa penanaman nilai-nilai kearifan lokal di MINU sebagai berikut:

1. Nilai-nilai keraifan lokal yang di tanamkan di MINU ada tiga yaitu: Tolong menolong, Solidaritas dan Gotong royong. Ketiga nilai-nilai tersebut sudah mencangkup semuanya yang ada dalam filosofi Sang Bumi Ruwa Jurai sebagai sistem nilai masyarakat Lampung yang bersandar pada Piil Pesenggiri yang meliputi Juluk-Adek Juluk-adek, Nemui-Nyimah, Nengah-Nyappur, Sakai-Sambaiyan, dan Titie Gemattei.

2. Strategi yang di gunakan dalam penanaman nilai-nilai kearifan lokal di MINU melalui pengintegrasikan nilai-nilai kearifan lokal dengan proses pembelajaran, pengintegrasikan nilai-nilai kearifan lokal dengan budaya sekolah dan pengintegrasikan nilai-nilai kearifan lokal dengan ekstrakulikuler.

\section{DAFTAR PUSTAKA}

Aunillah, Nurla Isna. panduan menerapkan pendidikan karakter di sekolah. Yogyakarta: Laksana. 2011

Dedi Rosala. Pembelajaran Seni Budaya Berbasis Kearifan Lokal Dalam Upaya Membangun Pendidikan Karakter Siswa Di Sekolah Dasar, RITME Vol ume 2 No. 1 Fe bruari 2016

Doni Koesoema, Pendidikan Karakter: Strategi Mendidik Anak di Zaman Global Jakarta: PT Grasindo, 2007

Endah Marwanti. Membangun Semangat Nasionalisme Di Sekolah Melalui Kearifan Lokal, Jurnal Pendidikan Ke-SD-an,Vol. 3, Nomor 1, September 2016

Huberman dan Miles. Qualitative Data Analisis, Terj Rosidi T.R . Jakarta: UI Press. 1992.

Nasution. Metode Research Penelitian Ilmiah. Jakarta: Bumi Aksara. 2001

Nurul Zuhriah. Pendidikan Moral dan Budi Pekerti dalam Perspektif Perubaban. Jakarta: Bumi Aksara. 2007

Saifuddin Anwar. Metodologi Penelitian. Yogyakarta: Pelajar Offset. 1998.

Sigit Dwi Santana K. Menulis Ilmiah Metode Penelitian Kualitatif. Jakarta: Yayasan Obor Indonesia. 2007.

Sularso. Revitalization Of Local Wisdom In Education, Jurnal Pendidikan Sekolah Dasar Vol. 2, No. 1 Desember 2016.

Ulfah Fajarini,. peranan kearifan lokal dalam pendidikan karakter, Jurnal Sosio Didaktika, Volume 1, no 2 Desember 2014 